5. Ставицька Л. Короткий словник жаргонної лексики української мови : Містить понад 3200 слів і 650 стійких словосполучень. Київ: Критика, 2003. 336 с.

6. Толстова О. Мотиваційні моделі фразеології іспанського молодіжного сленгу. Проблеми семантики, прагматики та когнітивної лінгвістики. 2012. Вип. 22. С. 308-315.

7. Шинкаренко I. Ненормативна лексика у молодіжному мовленні як відображення психологічних та соціальних конструктивів. Метафора та ї̈ семіотичний контекст: матеріали наук.-практ. семінару (Дніпро, 17 березня 2017 р.). Дніпро : ДДУВС, 2017. С. 48-52.

DOI https://doi.org/10.30525/978-9934-26-073-5-2-13

\title{
ДЕНОТАТИВНА ПРИРОДА ЗІСТАВЛЕННЯ УКРАЇНСЬКИХ ТА АНГЛІЙСЬКИХ НОМІНАЦІЙ ВІДПОВІДНИХ ПОНЯТЬ
}

\author{
Іваницька Н. Л. \\ доктор філологічних наук, професор, \\ професор кафедри украӥнської мови \\ Вінницького державного педагогічного університету \\ імені Михайла Кочюбинського \\ Родюк Н. Ю. \\ кандидат філологічних наук, доцент, \\ завідувач кафедри української мови \\ Вінницького державного педагогічного університету \\ імені Михайла Коияюбинського \\ Хіміч Г. I. \\ магістрантка кафедри украӥнської мови \\ Вінницького державного педагогічного університету \\ імені Михайла Кочюбинського \\ м. Вінниця, Україна
}

«Денотат», «мікроденотат», «денотативний аспект», «денотативна ситуація», «денотативний принцип», «денотативна сема» - ці, як i подібні терміни закріпилися в лінгвістиці. Узвичаєним став термінообсяг багатьох інших термінів, які об’єднує денотативний принцип (підхід) до 
вивчення, узагальнення й номінування мовних реальностей, наприклад: екстенціонал, десигнат, сигніфікат, референт, інтенсіонал та ін.

У словниках терміноназву «денотат» найчастіше пов'язують iз предметом думки, що «... відображає предмет або явище об'єктивної дійсності та утворює понятійний зміст, із яким співвідноситься мовна одиниця.

Нерідко сучасні вчені пов'язують денотат із семантичною структурою слова й трактують його в логічному аспекті як термін, транспонований у логіку, - відповідник значення «позначуваного» чи як «об’єкт (фрагмент) дійсності або ментального світу, позначені певною мовною одиницею відповідник референта [9, с. 86]. О. Селіванова, узагальнюючи трактування денотата різними ученими, зазначає, що «... на відміну від конотата, денотат у семантиці розглядається як понятійне ядро; значення, позбавлене суб'єктивних відтінків ознаки, емоційності, експресивності, функціонально-стилістичної забарвленості...» [9, с. 86]. А. Загнітко, користуючись номінацією «сутність», пов’язує зміст поняття, вербалізованого терміноназвою «денотат», із «кодованим мовним знаком, безвідносно щодо його природних чи диференційних ознак» [1, Т.1, с. 192]. Розширюючи зміст і, головне, функцію денотата, А. Загнітко навіть приписує денотативну роль агенсу, називаючи це «денатором» (англ. denator), у ситуації передавання матеріального об'єкта: Батько дав синові книжку [1, Т.1, с. 192]. Таке трактування понятійно-термінологічної одиниці «денотат» дозволило вченому обгрунтувати методологію й методику об'єднання різних мовних одиниць (слова, словосполучення, речення) в ракурсі їхнього вивчення на денотативній основі.

Автори Сучасного словника іншомовних слів [10] кваліфікують «денотат» (лат. denotatus - позначення), як : «... те, що називається цим словом, представником чого воно є в мові» [10, с. 210], об'єднуючи термінологічну сутність займенниковими назвами. Ми вважаємо, що «все», що в мові (мовах) певним чином називається, спроектоване на денотат як позамовний чинник, відтворений людською свідомістю i закріплений у мові (мовах) відрізком мовлення (словом, сполученням слів, фрагментом речення).

Поширилися в сучасній україністиці такі однослівні та кількаслівні терміноназви, як: «предметність», «прочесуальність», «словоназва предметного денотата», «словоназва процесуального денотата», коли йдеться про стрижневі параметри, на підставі яких відбувається об'єднання слів у великі групи та номінування таких груп за денотативними ознаками [2; 4; 7;]. Так, стрижневим параметром 
(узагальненим денотатом) для словоназв із ознакою предметність $\epsilon$ входження до цього класу словесних номінацій, які утворюють думку про предмет (вузьких, широких, конкретних, загальних, абстрактних, мовних, математичних, географічних та ін. понятійних реальностей). Денотативна ознака «предметність» об'єднує назви, які позначають: конкретні матеріальні явища, що сприймаються органами чуття (книга, a notebook); потреби людини (миска, a plate); те, на що спрямована пізнавальна, творча чи практична діяльність кого-/ чого-небудь (критика, criticism); коло знань (екзамен, ехатіnation) і т.д. і т.под. номінації предметних денотатів. Переважно вони виражають просту предметну віднесеність назв до реалій дійсності, в якій вичленовується денотат як ізольований елемент поза його зв'язками 3 іншими денотатами. Саме на цій основі утворилося розуміння природи предметного денотата та предметності $[4 ; 5]$.

Стрижневим параметром (узагальним денотатом) для дієслівних словоназв є процесуальність, орієнтована на процес як хід розвитку чогонебудь, послідовну зміну станів чи явищ у їхній динаміці, яка може бути поступовою, повільною, цілеспрямованою, біологічною, історичною та ін. Дієслівний денотат узагальнено кваліфікують як ономасіологічну сутність, що членується на три варіанти: процесуальність - дія, процесуальність - процес, прочесуальність - стан, із-поміж яких домінує у сфері дієсловоназв прочесуальність - дія (об’єднує дієслова із значенням дії, які номінують діяльність, породжувану людиною). Мовне вираження цього денотата може бути обмежене рамками лише однієї дієсловоназви (ивісти, гавкати, розкошувати, to sleep, to suffer, to тигтиr). Водночас номінація процесуального денотата може бути й кількаслівною із ядерним словом, що концентрує ономасіологічну сутність денотата. У результаті цього в мовах утворюються різного роду семантичні єдності 3 ядерною дієсловоназвою: двослівні (скласти екзамен, привласнити майно, допомогти вилікуватись, to meet the friend, to upgrade equipment, to combine efforts); кількаслівні (поводитись із ліками обережно, привітати маму квітами, поставити їжу на стіл, to supply goods to customers, to devote herself to charity, to make the way for the soldiers).

Неабияке значення, особливо в зіставному мовознавстві, має орієнтація на морфологічне вираження ядерних слів у ролі інтерпретаторів змістової сутності словоназв у словниках. Через відсутність, спричинену неможливістю чіткого визначення багатьох словоназв у їхньому конктретному значенні, вчені вдаються до використання принаймні двох способів дефінування, що їх забезпечує ресурсоспроможність конкретної мови. Найбільш придатними в цьому плані виступають українські 
займенникові форми 3 подальшими компенсаторами змісту. Наприклад: об'єкm (лат. objectus - предмет) - «... усе те, що є місцем якої-небудь діяльності [10, с. 461], абсолют (лат. absolutus - необмежений, довершений) - «щяось необмежене, довершене) [10, с. 13]. Частими виявляються також абстрактні іменникові словоназви в ролі інтерпретаторів змістової сутності іменникових словоназв. Наприклад: об'єктивність - «відповідність об'єктивній дійсності; неупередженість, причетність до об'єктивного пізнання» [10, с. 491]; абревіація (лат. abbreviatio - скорочення - творення слова шляхом довільного скорочення твірної одиниці [10, с. 13].

Водночас така об'єднувальна денотативна ознака може слугувати для пошуку корелятивних номінацій, властивих зіставним мовам із переважанням відповідних номінацій у конкретній мові. Взяти хоча б, наприклад, англійську дієсловоназву процесуального денотата to rise $\mathrm{i}$ порівняти ії з можливими відповідниками в реченнях української мови (компонентами відповідних мікроденотатів із варіантами базової семи): вставати, підводитись (англ. He rose and walked over to qreet me - укр. Він встав (підвівся) і підійшов до мене привітатися); прокидатися (англ. At what time do уои usually rise? - укр. O котрій годині ви зазвичай прокидаєтесь?).

Денотат (денотативний чинник) склав основу для порівняльного аналізу різнорівневих мовних одиниць, особливо словесних номінацій процесуального денотата [3].

Перспективу подальших досліджень мовних одиниць пов'язуємо із застосуванням до них статистичних методів аналізу стильових, жанрових та авторських різновидів мовлення [6].

\section{Література:}

1. Загнітко А. П. Словник сучасної лінгвістики: поняття і терміни: у 4 т. Донецьк : ДонНУ. 2012. Т. 1401 с., Т. 2 349с., Т. 3349 с., Т. 4387 с.

2. Іваницька Н. Б. Дієслівні системи української та англійської мов: парадигматика і синтагматика: монографія. Вінниця: СПД Главацька, $2011.636 \mathrm{c}$.

3. Іваницька Н. Б. Співвідношення дієслівних найменувань процесуальних денотатів в українській та англійській мовах. Українська мова. 2007. № 3. С. 44-53.

4. Іваницька Н. Л. Повнозначне слово в його проекції на денотат. Украӥнська мова. 2006. № 3. С. 48-56.

5. Іваницька Н. Л. Повнозначне слово української мови в сучасних категорійних вимірах: монографія. Вінниця : Нілан-ЛТД, 2017. 266 с. 
6. Іваницька Н. Л., Борейко Т. В. Статистика в мові науковотехнічного стилю. Science and education: problems, prospects and innovation. - Abstracts of International and Practical Conference. (Kyoto, Japan. 4-6 February, 2021) - C. 505-509.

7. Кочерган М. П. Основи зіставного мовознавства. Київ : Академія, 2006. $424 \mathrm{c}$.

8. Родюк Н. Семантико-теоретичний аналіз національно маркованої лексики історичного твору // Наукові записки Вінницького держсавного педагогічного університету імені Михайла Коиюбинського. Серія: Філологія (мовознавство): Зб. наук. праць / гол. ред. С. Б. Барань. Вінниця : ТОВ «Фірма Планер», 2020. Вип. 31. С. 71-77.

9. Селіванова О. О. Сучасна лінгвістика : напрями та проблеми : підручник. Полтава : Довкілля. Київ, 2008. 712 с.

10. Сучасний словник іншомовних слів. Близько 20 тис. слів і словосполучень / уклад. О. І. Скопненко, Т. В. Цимбалюк. Київ : Довіра, 2006. $789 \mathrm{c}$.

DOI https://doi.org/10.30525/978-9934-26-073-5-2-14

\title{
ТЕРМІН ЯК ОДИНИЦЯ МОВИ СПЕЦАЛЬНОГО ПРИЗНАЧЕННЯ В ЛІНГВІСТИЧНИХ ДОСЛІДЖЕННЯХ
}

\author{
Мельник П. В. \\ магістр філології, народний депутат України, \\ голова підкомітету з питань координації програм \\ технічної допомоги Свропейського Союзу та співпраиі з Свратомом \\ Комітету Верховної Ради Украӥни з питань інтеграції Украӥни \\ з Свропейським Союзом \\ м. Київ, Украӥна
}

Професійна підмова як феномен (субмова, підмова, соціальнопрофесійний варіант мови, мова спеціального призначення, LSP language for specific purposes) потрапляе в активний науковий обіг у другій половині XX ст. На першому етапі (60-80 рр. XX ст.) професійну підмову розглядають 3 позицій загального термінознавства та функціональної стилістики. Увага вчених зосереджена на формальних характеристиках мова спеціального призначення, iï лексичному складі й граматичних особливостях. Основними джерелами дослідження були наукові й технічні тексти. У 90 -ті роки XX ст. сформувалася особлива 